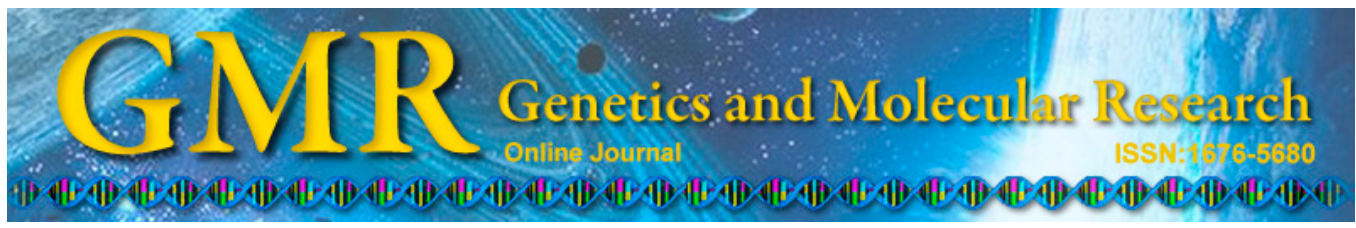

\title{
Delimiting invasive Myriophyllum aquaticum in Kashmir Himalaya using a molecular phylogenetic approach
}

\author{
M.A. Shah ${ }^{1}$, M.A. Ali ${ }^{2}$, F.M. Al-Hemaid ${ }^{2}$ and Z.A. Reshi ${ }^{1}$ \\ ${ }^{1}$ Department of Botany, University of Kashmir, Srinagar, India \\ ${ }^{2}$ Department of Botany and Microbiology, College of Science, \\ King Saud University, Riyadh, Saudi Arabia \\ Corresponding author: M.A. Ali \\ E-mail: alimohammad@ksu.edu.sa
}

Genet. Mol. Res. 13 (3): 7564-7570 (2014)

Received September 24, 2013

Accepted February 16, 2014

Published September 12, 2014

DOI http://dx.doi.org/10.4238/2014.September.12.23

ABSTRACT. Myriophyllum aquaticum (Vell.) Verdc. (family Haloragaceae) is one of the most invasive and destructive South American aquatic plant species and is present in a wide range of geographic regions, including the Kashmir Himalaya. Confusion regarding the taxonomic delimitation of $M$. aquaticum in the Himalayan region impedes effective and targeted management. Hence, our goal was improve the identification of M. aquaticum for exclusive delimitation from other related species in the study region using a molecular phylogenetic approach. A maximum parsimony tree recovered from phylogenetic analyses of the internal transcribed spacer sequences of nuclear ribosomal DNA was used to authenticate the identification of $M$. aquaticum. The results of this study can be used for targeted management of this tropical invader into the temperate Kashmir Himalaya.

Key words: Myriophyllum aquaticum; Kashmir Himalaya; India; Molecular authentication; Internal transcribed spacer; Invasion management 


\section{INTRODUCTION}

While the family Haloragaceae has been of special interest to botanists since the beginning of the 19th century, it remains poorly understood (Moody and Les, 2010). Several instances of errors in taxonomic classification in the family Haloragaceae have recently been overcome using data obtained from molecular phylogeny approaches (Moody and Les, 2007; Thum and Lennon, 2010; Thum et al., 2011). Myriophyllum L. (family Haloragaceae), commonly known as "water milfoil" is a cosmopolitan genus consisting of aquatic or semi-aquatic herbs. With approximately 68 species, the genus has 3 main centers of distribution, including Australia, India/Indochina, and North America. In the Kashmir Himalayan region, the genus Myriophyllum is represented by 4 species. These species include M. aquaticum (Vell.) Verdc, M. spicatum L., M. tuberculatum Roxb., and M. verticillatum L. (Arshid et al., 2011). M. spicatum is a destructive invasive species present in a wide range of geographical regions (Moody and Les, 2007). M. aquaticum (commonly referred to as parrot-feather) is another rapidly spreading congeneric species that has taken over marshy and aquatic habitats at different spatial scales in different temperate and tropical regions.

M. aquaticum has recently emerged as an aggressive invader with alarming impacts on aquatic habitats, particularly in the lakes and wetlands of the Kashmir Himalayan region (Shah and Reshi, 2012, 2014). Taxonomic inaccuracies and identification problems significantly limit targeted control measures and precise management strategies of this aquatic invasive species in the Himalayan valley of Kashmir. Although an attempt has recently been made to identify M. aquaticum based on morphological features (Arshid et al., 2011), correctly identifying such species using precise molecular approaches is very important. The internal transcribed spacer (ITS) sequences of nuclear ribosomal DNA (nrDNA) has gained much attention during the last two decades not only due to its efficacy in carrying out phylogeny of the plants at lower taxonomic level but also for its reorganization as the most trusted markers available for the DNA barcoding of the plants (Ali et al., 2013). Hence, the goal of the present study was to assess nrDNA ITS sequence-based molecular authentication and identification of M. aquaticum, and its exclusive delimitation from related or morphologically similar species.

\section{MATERIAL AND METHODS}

During the present study, 5 lakes (Anchar, Dal, Manasabal, Nigeen, and Wular) and 5 wetlands (Haigam, Hokersar, Rakhi-Arath, Shallabugh, and Mirgund) varying in depth, trophic status, and level of disturbance were surveyed for collection of M. aquaticum. At least five individuals were collected from each water body surveyed. Total genomic DNA was extracted using the DNeasy Plant Mini Kit from Qiagen. The nrDNA ITS regions were amplified using the primers ITS1 and ITS4 as described by White et al. (1990). Double-stranded polymerase chain reaction (PCR) products were produced via 35 cycles of $95^{\circ} \mathrm{C}$ for $1 \mathrm{~min}, 48^{\circ} \mathrm{C}$ for $1 \mathrm{~min}$, and $72^{\circ} \mathrm{C}$ for $1 \mathrm{~min}$, with a 10 -min final extension cycle at $72^{\circ} \mathrm{C}$. PCR products were purified using a SolGent PCR Purification kit-Ultra (SolGent, Daejeon, South Korea) and sequenced using the same primers using $2 \mu \mathrm{L}$ BigDye, $1 \mu \mathrm{L}$ primer $(20 \mathrm{pM})$, and template DNA and purified water to reach a $10-\mu \mathrm{L}$ reaction volume. Cycle sequencing used 25 cycles of $96^{\circ} \mathrm{C}$ for $10 \mathrm{~s}, 50^{\circ} \mathrm{C}$ for $5 \mathrm{~s}$, and $60^{\circ} \mathrm{C}$ for $4 \mathrm{~min}$. Sequencing products were visualized on an ABI Prism 377 automated DNA sequencer (Applied Biosystems, Foster City, CA, USA).

Sequences were edited using the ABI Sequence Navigator (Applied Biosystems). Each 
sequence generated was searched using the Basic Local Alignment Search Tool (BLAST) to identify sequence similarity to other Haloragaceae sequences available in GenBank. The sequences generated from the samples, including MAS1, MAS5, MAS6, and MAS9 (GenBank accession Nos. KC012919-KC012922) as well as MAS2, MAS3, MAS4, and MAS8 (GenBank accession Nos. KC012915-KC012918) showed similarity to Ceratophyllum demersum L. and Myriophyllum species, respectively; thus, only the second set of sequences were included in the data matrix for phylogenetic analyses. Sequences of Myriophyllum species available in the GenBank were retrieved (Table 1) and analyzed together with the sequences generated from the target species of the present study. Outgroup sequences were also retrieved from NCBI GenBank and included in the analysis. The sequences of Laurembergia repens (L.) P.J. Bergius, Gonocarpus montanus (Hook. f.) Orchard, Haloragis odontocarpa F. Muell. were selected as the outgroup (Table 1) because of their close phylogenetic relationship with Myriophyllum and based on the results of previous studies (Moody and Les, 2010). Sequence alignment of the final data set was performed using CLUSTAL_X version 1.81 (Thompson et al., 1997). Aligned sequences were then subsequently manually adjusted using BioEdit (Hall, 1999). The data matrix as a nexus file were exported to MEGA5 (Tamura et al., 2011) and analyzed using maximum parsimony (MP) methods. Insertion-deletions (indels) were scored as single characters when we had confidence in positional homology. The MP tree was obtained using the close-neighbor-interchange algorithm (Nei and Kumar, 2000) using search level 3 (Felsenstein, 1985; Nei and Kumar, 2000), in which initial trees were obtained using a random addition of sequences (10 replicates).

Table 1. Taxon and GenBank accession numbers included in the molecular phylogenetic analysis.

\begin{tabular}{|c|c|}
\hline Taxon & GenBank accession No. \\
\hline Myriophyllum alpinum Orchard & EF178720 \\
\hline Myriophyllum aquaticum (Vell.) Verdc. & EF526367 \\
\hline Myriophyllum aquaticum (Vell.) Verdc. (MAS2)* & KC012915 \\
\hline Myriophyllum aquaticum (Vell.) Verdc. (MAS3)* & KC012916 \\
\hline Myriophyllum aquaticum (Vell.) Verdc. (MAS4)* & KC012917 \\
\hline Myriophyllum aquaticum (Vell.) Verdc. (MAS8)* & KC012918 \\
\hline Myriophyllum crispatum Orchard & EF178721 \\
\hline Myriophyllum drummondii Benth. & EF178725 \\
\hline Myriophyllum farwellii & EF178731 \\
\hline Myriophyllum heterophyllum Michx. & AF513824 \\
\hline Myriophyllum hippuroides Nutt. & FJ870946 \\
\hline Myriophyllum humile (Raf.) Morong & EF526393 \\
\hline Myriophyllum latifolium F. Muell. & EF178729 \\
\hline Myriophyllum laxum Shuttlew. ex Chapm. & FJ870948 \\
\hline Myriophyllum limnophilum Orchard & FJ870949 \\
\hline Myriophyllum lophatum Orchard & EF178718 \\
\hline Myriophyllum papillosum Orchard & EF178724 \\
\hline Myriophyllum pinnatum (Walter) Britton, Sterns \& Poggenb. & FJ870966 \\
\hline Myriophyllum quitense Kunth & FJ870954 \\
\hline Myriophyllum robustum Hook. f. & FJ870955 \\
\hline Myriophyllum sibiricum Kom. & FJ426352 \\
\hline Myriophyllum simulans Orchard & EF178719 \\
\hline Myriophyllum spicatum L. & EF526362 \\
\hline Myriophyllum tenellum Bigelow & EF526410 \\
\hline Myriophyllum ussuriense Maxim. & EF178726 \\
\hline Myriophyllum variifolium Hook.f. & FJ870959 \\
\hline Myriophyllum sp (Aq-red1) & JF717420 \\
\hline Myriophyllum sp (red1) ${ }^{\circ}$ & FJ870962 \\
\hline Gonocarpus montanus (Hook. f.) Orchard & EF178770 \\
\hline Haloragis odontocarpa F. Muell. & EF178747 \\
\hline Laurembergia repens (L.) P.J. Bergius & EF178735 \\
\hline
\end{tabular}

*Sequence generated in the present study, and submitted to GenBank; †Thum et al. (2012); ${ }^{\circ}$ Moody and Les (2010). Abbreviations MAS2, MAS3, MAS4, and MAS8 next to the name of the taxon represents the accessions of Myriophyllum aquaticum collected from aquatic habitats of Kashmir Himalaya. 


\section{RESULTS AND DISCUSSION}

Field surveys of all investigated lakes and wetlands in the Kashmir Himalaya revealed a high incidence of $M$. aquaticum with a distinct colonization preference along the littoral regions and more shallow waters of invaded habitats. In nearly all surveyed water bodies, M. aquaticum exhibited formation of green mat-like homogenous patches with a fast-spreading tendency and development of inroads from littoral marshy regions to more open water areas (Figure 1).

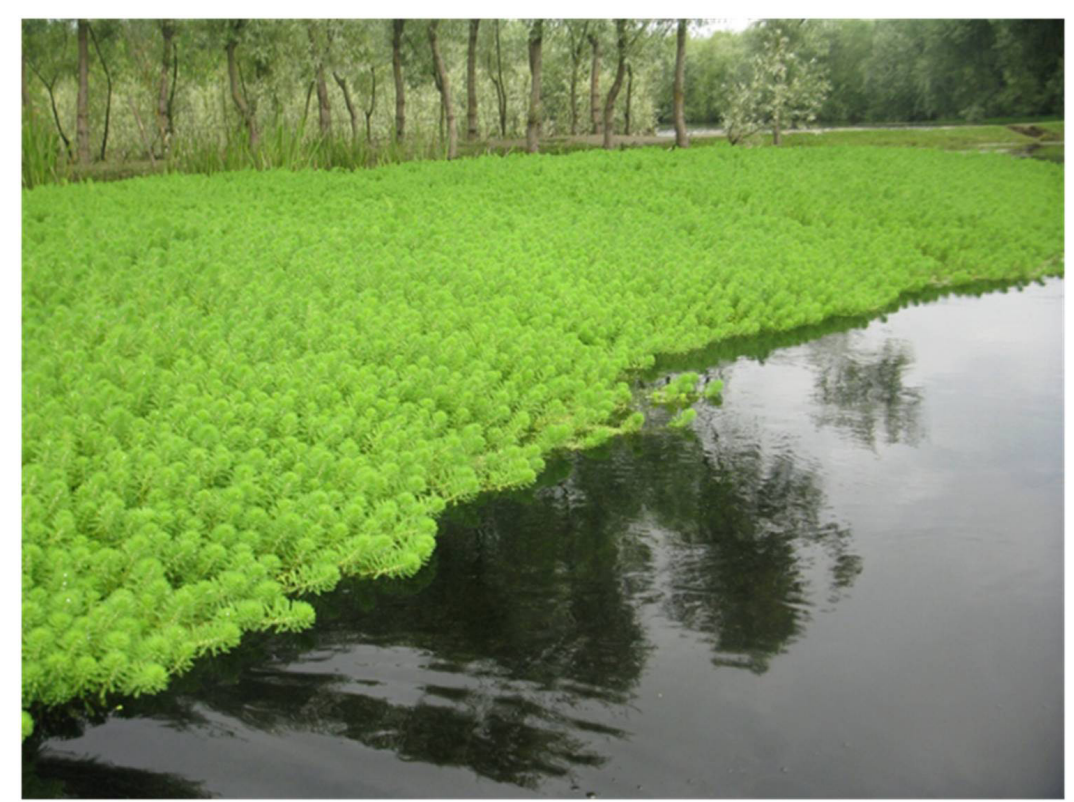

Figure 1. A view of invasion by Myriophyllum aquaticum from Shallabugh wetland of Kashmir Himalaya.

Morphological investigation showed bright green and slender stems, stem leafy throughout and bearing simple, oblong, feathery, and whorled leaves. Both submersed and emergent leaves were present, inflorescence was generally emergent, the plants were dioecious and terminal with inconspicuous flowers, and without petals borne in emergent leaf axils.

Parsimony analysis of the entire ITS region resulted in 26 maximally parsimonious trees with a total length of 331 steps, consistency index of 0.639 , composite index of 0.598 , and retention index of 0.849 (Figure 2). The Myriophyllum accessions, which included MAS2, 3 , 4, and 8, showed proximity (bootstrap support $99 \%$ ) to the accessions of $M$. aquaticum from GenBank (FJ870962, EF526367, and F717420). The ITS genotypes of sequenced accessions of Myriophyllum were identical to GenBank accession EF526367; however, the sequences differed from FJ870962 by 1-2 nucleotide substitutions according to sequence alignment at various positions, including 39, 104, 112, 144, 147-148, 157, 172, 180, 215, 218, 219, 420, and 553, and 3 small indels of 1-4 base pairs each, including at sequence alignment position 86-90, 141, and 153-155. Of these, nucleotide substitutions at sequence alignment position 39 and 111 were not consistent with those of F717420. These differences in ITS genotypes may be due to polymorphisms, which are frequently observed in this gene (Bailey et al., 2003; Pandey and Ali, 2006; Xiao et al., 2010); however, the short sequence length of JF717420 at 
the beginning and towards the end as compared with the other GenBank accessions of Myriophyllum is interesting and should be further evaluated.

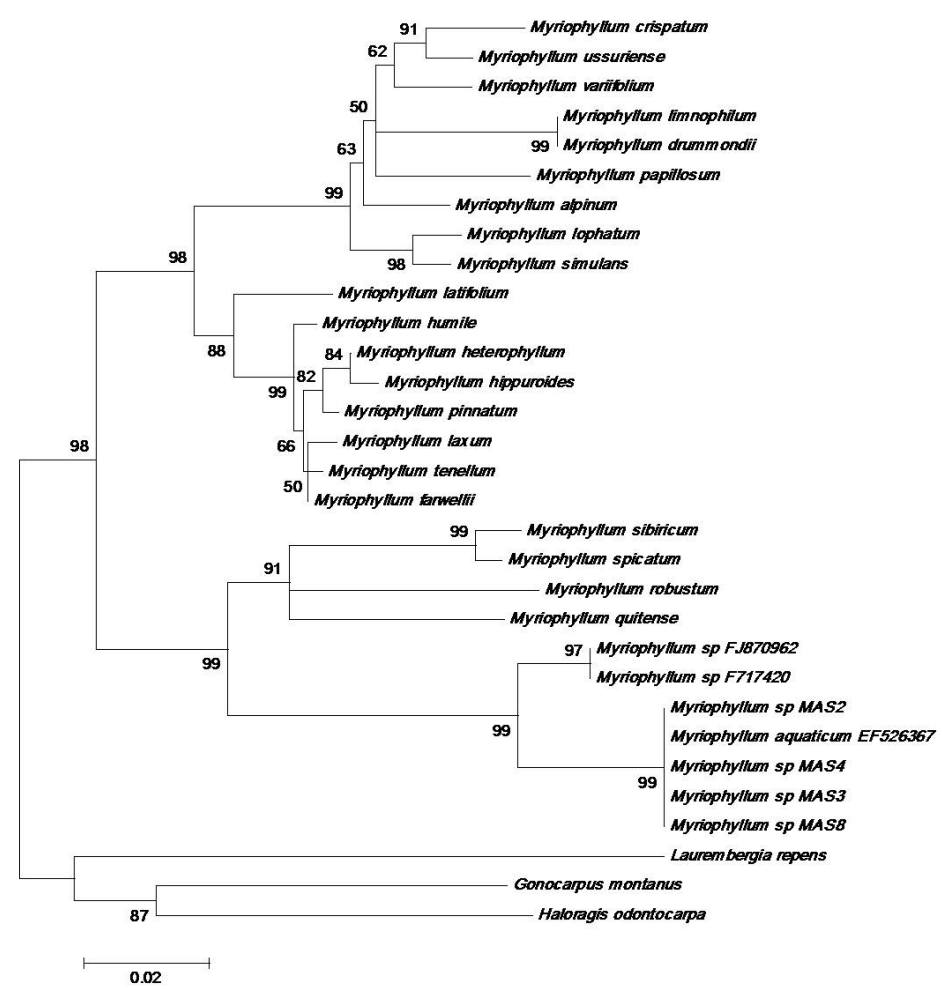

Figure 2. Maximum parsimony tree inferred from analyses of internal transcribed spacer sequence of nuclear ribosomal DNA. Taxon nomenclature and accession name follow Moody and Les (2010) and Thum et al. (2012) respectively. Numbers on the nodes are bootstrap support under 1000 bootstrap replicates for maximum parsimony analysis.

Precisely identifying M. aquaticum in Kashmir Himalaya using both morphological and molecular phylogenetic approaches is important because invasion managers are unambiguously using targeted biological and chemical control strategies against M. aquaticum. Specific biological control agents have been already developed to combat M. aquaticum (Cilliers, 1999; Gassmann et al., 2006). After clear delimitation of M. aquaticum, taxonomists and wetland managers in Kashmir, who quite often overlap the taxonomic identity of different species of Myriophyllum, can use specific biocontrol agents to manage this species.

Because of its widespread dominance in all the aquatic habitats, particularly in the Kashmir Himalaya, M. aquaticum has recently been classified (Shah and Reshi, 2012) as Stage V species (Colautti and MacIsaac, 2004). Climate changes have caused some tropical species such as Azolla cristata Kaulf. to expand their ranges to typically temperate regions, including Kashmir Himalaya. Although M. aquaticum is native to tropical South America, it behaves as a global pest species, invading many temperate regions as well. This further complicates the delimitation of different species of Myriophyllum as they appear similar to other tropical species of the family Haloragaceae, such as L. repens, which may be present in the Kashmir valley. 
In conclusion, in addition to morphological attributes, molecular phylogenetic analysis based on nrDNA authenticated the identification of M. aquaticum in Kashmir Himalaya. The results have important taxonomic ramifications and can be used to guide biodiversity managers in effective and targeted management of this aggressive invasive species in the Himalayan region.

\section{ACKNOWLEDGMENTS}

Research supported by the King Saud University, Deanship of Scientific Research, College of Science, Research Center.

\section{REFERENCES}

Ali MA, Al-Hemaid FM, Choudhary RK, Lee J, et al. (2013). Status of Reseda pentagyna Abdallah \& A.G. Miller (Resedaceae) inferred from analysis of combined nuclear ribosomal and chloroplast sequence data. Bangl. J. Plant. Taxon. 20: 233-238.

Arshid S, Wani AA, Ganie AH, Khuroo AA, et al. (2011). On correct identification, range expansion and management implications of Myriophyllum aquaticum in Kashmir Himalaya, India. Checklist 3: 299-302.

Bailey CD, Carr TG, Harris SA and Hughes CE (2003). Characterization of angiosperm nrDNA polymorphism, paralogy, and pseudogenes. Mol. Phylogenet. Evol. 29: 435-455.

Cilliers CJ (1999). Lysathian sp. (Coleoptera: Chrysomelidae), a host-specific beetle for the control of the aquatic weed Myriophyllum aquaticum (Haloragaceae) in South Africa. Hydrobiologia 415: 271-276.

Colautti RI and MacIsaac HI (2004). A neutral terminology to define 'invasive' species. Divers 10: 135-141.

Felsenstein J (1985). Confidence limits on phylogenies: an approach using the bootstrap. Evolution 39: 783-791.

Gassmann A, Cock MJW, Shaw R and Evans CH (2006). The potential for biological control of invasive alien aquatic weeds in Europe: a review. Hydrobiologia 570: 217-222.

Hall TA (1999). BioEdit: a user-friendly biological sequence alignment editor and analysis program for Windows 95/98/ NT. Nucleic Acids Sym. Ser. 41: 95-98.

Moody ML and Les DH (2007). Phylogenetic systematics and character evolution in the angiosperm family Haloragaceae. Am. J. Bot. 94: 2005-2025.

Moody ML and Les DH (2010). Systematics of the aquatic angiosperm genus Myriophyllum (Haloragaceae). Syst. Bot. 35: 121-139.

Nei M and Kumar S (2000). Molecular Evolution and Phylogenetics. Oxford University Press, New York.

Pandey AK and Ali MA (2006). Molecular Markers in Plant Systematics I: Nuclear Sequences. In: Plant Sciences Research in India: Challenges and Prospects (Kumar S, ed.). Botanical Survey of India, Dehradun, 21-36.

Shah MA and Reshi Z (2012). Invasion by Alien Macrophytes in Freshwater Ecosystems of India. In: Invasive Alien Plants: an Ecological Appraisal for the Indian Subcontinent (Bhatt JR, Singh JS, Singh SP, Tripathi RS, et al., eds.). CABI, Wallingford, 199-216.

Shah MA and Reshi Z (2014). Characterization of alien aquatic flora of Kashmir Himalaya: implications for invasion management. Trop. Ecol. 55: 143-157.

Tamura K, Peterson D, Peterson N, Stecher G, et al. (2011). MEGA5: molecular evolutionary genetics analysis using maximum likelihood, evolutionary distance, and maximum parsimony methods. Mol. Biol. Evol. 28: 2731-2739.

Thompson JD, Gibson TJ, Plewniak F, Jeanmougin F, et al. (1997). The CLUSTAL_X windows interface: flexible strategies for multiple sequence alignment aided by quality analysis tools. Nucleic Acids Res. 25: 4876-4882.

Thum RA and Lennon JT (2010). Comparative ecological niche models predict the invasive spread of variable-leaf milfoil (Myriophyllum heterophyllum) and its potential impact on closely related native species. Biol. Invasions 12: 133-143.

Thum RA, Zuellig MP, Moody ME, Johnson RL, et al. (2011). Molecular markers reconstruct the invasion history of variable leaf water milfoil (Myriophyllum heterophyllum) and distinguish it from closely related species. Biol. Invasions 13: 1687-1709.

Thum RA, Mercer AT and Wcisel DJ (2012). Loopholes in the regulation of invasive species: genetic identifications identify mislabeling of prohibited aquarium plants. Biol. Invasions 14: 929-937.

White TJ, Bruns T, Lee S and Taylor J (1990). Amplification and Direct Sequencing of Fungal Ribosomal RNA Genes for Phylogenetics. In: PCR Protocols: A Guide to Method and Amplifications (Innis MA, Gelfand DH, Sninksky JJ and 
White TJ, eds.). Academic Press, San Diego, 315-322.

Xiao LQ, Moller M and Zhu H (2010). High nrDNA ITS polymorphism in the ancient extant seed plant Cycas: incomplete concerted evolution and the origin of pseudogenes. Mol. Phylogenet. Evol. 55: 168-177. 